Bangladesh J. Plant Taxon. 16(1): 57-63, 2009 (June)

(C) 2009 Bangladesh Association of Plant Taxonomists

\title{
OCCURRENCE OF CHROOCOCCACEAE DURING RICE CULTIVATION IN NORTH BIHAR, INDIA
}

\author{
Kaushal Kishore ChOUdhary ${ }^{1}$ \\ Department of Botany, B.R.A. Bihar University, Muzaffarpur 842 001, Bihar, India. \\ Keywords: Chroococcaceae; Cyanobacteria; Rice cultivation; North Bihar; India.
}

\begin{abstract}
The species richness of cyanobacteria belonging to the family Chroococcaceae in rice fields of North Bihar, India was studied over a 60-day period. Twenty-eight species representing nine genera were identified. The highest number of 21 species was observed around $30^{\text {th }}$ day against eight and 13 species around $10^{\text {th }}$ and $60^{\text {th }}$ day of rice cultivation, respectively. Aphanocapsa grevillei (Hass.) Rabenh., Aphanothece naegelii Wartm and Microcystis marginata (Menegh.) Kützing were observed from $10^{\text {th }}$ to $60^{\text {th }}$ days of rice cultivation.
\end{abstract}

\section{Introduction}

Cyanobacteria are geographically widespread in freshwater, marine and terrestrial habitats. Some genera are capable of nitrogen fixation and are therefore of great importance for the balance in ecosystems. With the establishment of agronomic potential of cyanobacteria (De, 1939), the distribution of cyanobacteria and their role in maintaining soil fertility has variously been studied throughout the world (Begum et al., 1993, 1996, 2008; Khan et al., 1994; Singh et al., 2001). Cyanobacteria have been reported to promote the nitrogen economy of the soil by converting atmospheric nitrogen into soluble form of ammonia with the help of enzyme nitrogenase complex contained within the specialized structure heterocyst (Ernst et al., 1992). Additionally, cyanobacteria contribute phosphorus to the soil by mobilizing the insoluble phosphate present in the soil with enzyme phosphatases (Mishra et al., 2005). Moreover, cyanobacteria enhance the water holding capacity by adding polysaccharidic materials to the soil (Choudhary et al., 2007) and increase the soil aggregation property. Cyanobacteria have also been reported to excrete growth promoting substances into the soil (Gupta and Shukla, 1969).

Rice is one of the main crops of Bihar and is cultivated in most part of the state. Rice fields favour the growth of cyanobacteria in terms of light, temperature, $\mathrm{pH}$, humidity, water and nutrient availability (Mitra, 1951). Heterocystous forms of cyanobacteria have been extensively studied for their diversity in rice fields (Singh, 1961; Choudhary, 1999). The information on systematic enumeration of non-nitrogen-fixing forms including Chroococcaceae in the rice fields is limited. This study has been aimed to enumerate the periodic occurrence of Chroococcaceae in some rice fields of North Bihar, India.

1E-mail: kkc1970@gmail.com 


\section{Materials and Methods}

The study was conducted in some rice fields of Muzaffarpur district (latitude $26^{\circ} 7^{\prime} 12^{\prime \prime} \mathrm{N}$ and longitude $85^{\circ} 24^{\prime} 0^{\prime \prime} \mathrm{E}$ ) of North Bihar. Cyanobacterial occurrence in rice fields has been documented in terms of cultivation cycle. The cyanobacterial diversity was enumerated randomly around $10^{\text {th }}, 30^{\text {th }}$ and $60^{\text {th }}$ days of plantation of rice seedlings in rice fields.

Cyanobacterial samples growing in heterogeneous assemblage were randomly collected from upland and lowland rice fields representing the terrestrial as well as freefloating masses. The samples were collected in culture tube $(50 \mathrm{ml})$ and brought to the laboratory. The taxonomic enumeration was performed with fresh materials in the laboratory. The taxa were identified with the help of Desikachary (1959).

\section{Results and Discussion}

The study revealed 28 species belonging to nine genera of Chroococcaceae described below.

\section{Class: Cyanophyceae; Order: Chroococcales; Family: Chroococcaceae}

1. Aphanocapsa biformis A. Br., in Rabenhorst, Fl. Eur. Alg. 2: 246 (1865). Thallus olive-green; cells 4-7 $\mu \mathrm{m}$ in diameter, spherical, mostly with a mucilaginous envelope, loosely arranged, 2-4 together in the envelope, nannocytes present.

2. Aphanocapsa grevillei (Hass.) Rabenh., Fl. Eur. Alg. 2: 50 (1865), [Syn.: Microcystis gravillei (Hassall) Elenkin]. Cells spherical, 4.0-5.8 $\mu \mathrm{m}$ in diameter, closely arranged in homogeneous mucilage, individual envelopes not distinct.

3. Aphanocapsa koordersi Strom, Algol. notes, Nyt Mag. Naturvid. 61: 128 (1923). Colonies spherical; cells spherical, loosely arranged 2.3-3.2 $\mu \mathrm{m}$ in diameter.

4. Aphanothece bullosa (Menegh.) Rabenh., Fl. Eur. Alg. 2: 65 (1865). Thallus spherical; cells cylindrical, 6.5-12.3 $\mu \mathrm{m}$ long, 3.8-5.8 $\mu \mathrm{m}$ broad, without individual envelope.

5. Aphanothece castagnei (Bréb.) Rabenh., Fl. Eur. Alg. 2: 64 (1865). Thallus gelatinous and indefinite in shape, slimy; cells cylindrical, 4-8 $\mu \mathrm{m}$ long, 2.0-3.6 $\mu \mathrm{m}$ broad, sheath diffluent, colourless.

6. Aphanothece conferta Richter, in Hauck and Richter, Phyk. Univ. 10: 487 (1892). Thallus gelatinous; cells spherical, 2.5-3.0 $\mu \mathrm{m}$ in diameter, sheath diffluent, colourless.

7. Aphanothece naegelii Wartm, in Rabenhorst, Fl. Eur. Alg. 2: 65 (1865). Thallus gelatinous; cells oval or spherical, 3.5-4.5 $\mu \mathrm{m}$, blue-green, sheath diffluent. 
8. Aphanothece pallida (Kütz.) Rabenh., Fl. Eur. Alg. 2: 64 (1865). Cells oblong, 7-12 $\mu \mathrm{m}$ long, 5.3-6.5 $\mu \mathrm{m}$ broad without envelope and 11.5-20.3 $\mu \mathrm{m}$ long, 8.4-16.6 $\mu \mathrm{m}$ broad with envelope, sheath lamellated.

9. Aphanothece stagnina (Spreng.) A. Br., in Rabenhorst, Fl. Eur. Alg. 2: 66 (1865). Thallus gelatinous, spherical, ellipsoidal; cells oblong, more or less ovoid or cylindrical, 4.5-10.0 $\mu \mathrm{m}$ long, 3.0-6.5 $\mu \mathrm{m}$ broad.

10. Chroococcus macrococcus (Kütz.) Rabenh., Krypto. fl. Sachsen 1: 70 (1863). Thallus mucilaginous; cells spherical, 2-4 together, 21-40 $\mu \mathrm{m}$ in diameter without sheath and 26-64 $\mu \mathrm{m}$ in diameter with sheath, sheath lamellated.

11. Chroococcus minor (Kütz.) Näg., Gatt. einzell. Algen 47 pl. 1, A, fig. 4 (1849). Cells spherical, 3.5-4.0 $\mu \mathrm{m}$ in diameter, cells single or two together, sheath hyaline and thin.

12. Chroococcus minutus (Kütz.) Näg., Gatt. einzell. Algen 46 (1849). Cells spherical, 2-4 in a group, 4.8-8.6 $\mu \mathrm{m}$ in diameter without sheath, $8-14 \mu \mathrm{m}$ in diameter with sheath, sheath hyaline.

13. Chroococcus tenax (Kirchner) Hieron., Beitr. Biol. Pfl. 5: 483, pl. 17, fig. 11 (1892). Cells spherical and in a group of 2-4 cells, $16-21 \mu \mathrm{m}$ in diameter without sheath and 20-26 $\mu \mathrm{m}$ in diameter with sheath, sheath colourless and lamellated.

14. Gloeocapsa atrata (Turp.) Kütz., Phyc. generalis: 172 (1843). Thallus mucilaginous, blackish; cells 3.5-4.5 $\mu \mathrm{m}$ in diameter without sheath and 9-14.4 $\mu \mathrm{m}$ in diameter with sheath, cells many in colony, sheath colourless, thick and unlamellated.

15. Gloeocapsa decorticans (A. Br.) Richter, ex Wille, Nyt. Mag. Naturvid. 62: 186 (1925). Cells spherical or oval, single or 2-4 together, single cells $8.0 \mu \mathrm{m}$ in diameter without sheath and $19 \mu \mathrm{m}$ in diameter with sheath, sheath thick and distinctly lamellated.

16. Gloeocapsa gelatinosa Kütz., Phyc. generalis: 174 (1843). Cells 1.5-2.2 $\mu \mathrm{m}$ in diameter without sheath and 5.4-8.4 $\mu \mathrm{m}$ in diameter with sheath; colonies $20 \mu \mathrm{m}$ in diameter.

17. Gloeocapsa punctata Näg., ex Kützing, Species Algarum: 22 (1849). Thallus gelatinous; cells without sheath $0.7-1.5 \mu \mathrm{m}$ in diameter and with sheath 3.5-7.0 $\mu \mathrm{m}$ in diameter, sheath thick, colourless and unlamellated.

18. Gloeothece fusco-lutea Näg., Gatt. einzell. Algen: 58 (1849). Cells cylindrical, 4-8 together in envelope, cells without sheath $6.5-11.5 \mu \mathrm{m}$ long and $4.2-5.6 \mu \mathrm{m}$ broad, sheath brown. 
19. Gloeothece rupestris (Lyngb.) Bornet, Alg. de Schousb., Mem. Soc. Sci. Nat. Math. de Cherbourg 28: 177 (1892). Cells cylindrical with rounded ends, 12-14 $\mu \mathrm{m}$ long and 6-9 $\mu \mathrm{m}$ broad without hyaline mucilaginous sheath, 2-4 cells together in a common sheath, cells with sheath 15-24 $\mu \mathrm{m}$ long and 10-16 $\mu \mathrm{m}$ broad.

20. Merismopedia aeruginea Bréb., in Kützing, Species Algarum: 472 (1849). Colony of 16-64 ovate or hemispherical cells, very regularly arranged to form quadrangular colonies, colonies 32-52 $\mu \mathrm{m}$ broad; cells spherical, 4-5 $\mu \mathrm{m}$ in diameter.

21. Merismopedia glauca (Ehrenb.) Näg., Gatt. einzell. Algen: 55, pl. 1D, fig. 1 (1849). Colonies 40-120 $\mu \mathrm{m}$ in diameter with 8-32 cells; cells spherical, closely arranged, 3.5-5.5 $\mu \mathrm{m}$ broad.

22. Microcystis aeruginosa Kütz., Tab. Phycologicae 1: 8, pl. 8, fig. 1 (1846). Colonies round or slightly longer than broad, solid with distinct hyaline colonial mucilage; cells spherical, 3.5-7.0 $\mu \mathrm{m}$ in diameter, generally with gas vacuoles.

23. Microcystis elabens (Bréb.) Kütz., in Kützing, Tab. Phycologicae 1: 6, pl. 8 (1846). Colonies spherical, cells oblong, 4.0-8.5 $\mu \mathrm{m}$ long, 2.0-4.5 $\mu \mathrm{m}$ broad and with gas vacuoles.

24. Microcystis flos-aquae (Wittr.) Kirchner, in Engler and Prantl, Natürlichen Pflanzenfam. I. (1a): 56, fig. 49 (N) (1898). Colonies spherical to ellipsoidal with distinct colonial mucilage; cells spherical, 3.0-6.5 $\mu \mathrm{m}$ in diameter, with gas vacuoles, nannocytes present.

25. Microcystis marginata (Menegh.) Kütz., Tab. Phycologicae 1: 6, pl. 8 (1845-49). Colony round or irregularly flattened, single colony ellipsoidal to ovoid in outline, 140-150 $\mu \mathrm{m}$ long and 60-95 $\mu \mathrm{m}$ broad; cells spherical, 3-6 $\mu \mathrm{m}$ in diameter, closely arranged and with gas vacuoles.

26. Synechococcus aeruginosus Näg., Gatt. einzell. Algen: 56, pl. 1, E, fig. 1 (1849). Thallus up to $3 \mathrm{~cm}$ in diameter; cells oblong to cylindrical, $12-20 \mu \mathrm{m}$ long, 5.6-10.0 $\mu \mathrm{m}$ broad .

27. Synechocystis aquatilis Sauv., Bull. Soc. Bot. France 39: 121, pl. 6, fig. 2 (1892). Cells spherical, single or two together, 4.5-5.5 $\mu \mathrm{m}$ in diameter, pale-green in colour.

28. Synechocystis pevalekii Ercegovic, Acta Bot. Inst. Bot. Univ. R. Zagreb 1: 77, pl. 1, fig. 8 (1925). Thallus indefinite, cells spherical, 2.5-3.5 $\mu \mathrm{m}$ in diameter, single or two together.

The enumeration of cyanobacteria revealed the maximum diversity during the midcultivation cycle of the rice fields (Table 1). The study showed maximum 21 species around $30^{\text {th }}$ day of rice plantation followed by around $60^{\text {th }}$ day (13 species) and minimum around $10^{\text {th }}$ days ( 8 species). The occurrence of lesser number of forms during early cultivation stage might be attributed to the inhibitory effect of high light intensity, 
whereas fewer forms in the later part might be due to loss of nutrients as well as low light intensity reaching to the surface due to increased rice canopy. This was in agreement of the cyanobacterial distribution reported by Gupta (1966). The poor distribution of cyanobacteria in high light intensity suggested them to be sensitive to high light intensity and as low-light species (Roger and Reynaud, 1979; Choudhary, 2009).

Table 1. Presence and absence of species of Chroococcaceae in rice fields (upland and lowland) of North Bihar during rice cultivation. $+=$ Presence; $-=$ Absence; $R=$ Rare.

\begin{tabular}{|c|c|c|c|c|}
\hline S1. No. & Species & $10^{\text {th }}$ day & $30^{\text {th }}$ day & $60^{\text {th }}$ day \\
\hline 1. & Aphanocapsa biformis & - & + & - \\
\hline 2. & Aphanocapsa grevillei & + & + & + \\
\hline 3. & Aphanocapsa koordersi & - & + & + \\
\hline 4. & Aphanothece bullosa & + & + & - \\
\hline 5. & Aphanothece castagnei & - & - & $\mathrm{R}$ \\
\hline 6. & Aphanothece conferta & - & + & + \\
\hline 7. & Aphanothece naegelii & + & + & + \\
\hline 8. & Aphanothece pallida & - & + & + \\
\hline 9. & Aphanothece stagnina & + & + & - \\
\hline 10. & Chroococcus macrococcus & - & + & - \\
\hline 11. & Chroococcus minor & - & + & - \\
\hline 12. & Chroococcus minutus & + & + & - \\
\hline 13. & Chroococcus tenax & - & $\mathrm{R}$ & - \\
\hline 14. & Gloeocapsa atrata & - & - & $\mathrm{R}$ \\
\hline 15. & Gloeocapsa decorticans & - & - & + \\
\hline 16. & Gloeocapsa gelatinosa & - & $\mathrm{R}$ & - \\
\hline 17. & Gloeocapsa punctata & - & - & $\mathrm{R}$ \\
\hline 18. & Gloeothece fusco-lutea & - & $\mathrm{R}$ & - \\
\hline 19. & Gloeothece rupestris & - & $\mathrm{R}$ & - \\
\hline 20. & Merismopedia aeruginea & - & - & $\mathrm{R}$ \\
\hline 21. & Merismopedia glauca & - & - & $\mathrm{R}$ \\
\hline 22. & Microcystis aeruginosa & + & + & - \\
\hline 23. & Microcystis elabens & - & + & - \\
\hline 24. & Microcystis flos-aquae & + & + & - \\
\hline 25. & Microcystis marginata & + & + & + \\
\hline 26. & Synechococcus aeruginosus & - & - & + \\
\hline 27. & Synechocystis aquatilis & - & $\mathrm{R}$ & - \\
\hline 28. & Synechocystis pevalekii & - & $\mathrm{R}$ & - \\
\hline
\end{tabular}

The proliferation of non-nitrogen-fixing members of Chroococcaceae during midcultivation cycle might further be attributed to the availability of sufficient nitrogen along with other nutrients in the rice fields with suitable light intensity. Singh (1978) also reported the development of non-nitrogen-fixing forms in rice fields. He further described the early appearance of nitrogen-fixing forms in unfertilized plots than fertilized ones. It 
might be proposed that the appearance of non-nitrogen-fixing forms in rice fields might play an important role in establishment of nitrogen fixers by reducing the nitrogen status of the field by utilizing nutrients, particularly nitrogen. In this way, non-nitrogen fixers play a significant role in nutrient cycling and development of other biological system to fill up the gap produced in terms of nutrients.

Finally, it might be concluded that the documentation on cyanobacteria may enhance the understanding of the nutrient status of the field and might be applied for sustainable agricultural practices by reducing the application of chemical fertilizer to avoid the appearance of non-nitrogen fixers in the soil that might compete with nitrogen fixers for nutrients (Agawin et al., 2007).

\section{Acknowledgements}

The author is grateful to Head, Department of Botany, B.R.A. Bihar University, Muzaffarpur, Bihar for providing laboratory facilities and Prof. R. Bimal for his guidance and suggestions. This communication is a part of the $\mathrm{PhD}$ programme of the author.

\section{References}

Agawin, N.S.R., Rabouille, S., Veldhuis, M.J.W., Servatius, L., Hol, S., van Overzee, H.M.J. and Huisman, J. 2007. Competition and felicitation between unicellular nitrogen-fixing cyanobacteria and non-nitrogen fixing phytoplankton species. Limnol. Oceanogr. 52(5): 2233-2248.

Begum, Z.N. Tahmida, Khan, Z.U.M., Mandal, R. and Hossain, M.Z. 1993. Distributional pattern of nitrogen fixing cyanobacteria in rice fields of Bangladesh. Phykos 32(1\&2): 109-114.

Begum, Z.N. Tahmida, Mandal, R. and Amin, F.B. 2008. Quantification and nitrogen fixation of cyanobacteria in rice field soils of Bangladesh. Bangladesh J. Bot. 37(2): 183-188.

Begum, Z.N. Tahmida, Mandal, R., Khan, Z.U.M. and Hossain, M.Z. 1996. Prospect and potentiality of cyanobacteria as an alternative source of nitrogen fertilizer in Bangladesh rice cultivation. In: Rahman, M., Podder, A.K., Hove, C., Begum, Z.N. Tahmida, Heulin, T., and Harmann, A. (eds), Biological Nitrogen Fixation Associated with Rice Production. Kluwer Academic Publishers, Great Britain, pp. 119-131.

Choudhary, K.K. 1999. Ex-situ conservation of cyanobacterial germplasm of North Bihar, India, PhD Thesis, B.R.A. Bihar University, Muzaffarpur, Bihar, India.

Choudhary, K.K. 2009. Ecological and biotechnological relevance of cyanobacteria. In: Gupta, R.K., Kumar, M. and Vyas, D. (eds), Soil Microflora. Daya Publishing House, New Delhi, pp. 324-339.

Choudhary, K.K., Singh, S.S. and Mishra, A.K. 2007. Nitrogen fixing cyanobacteria and their potential applications. In: Gupta, R.K. and Pandey, V.D. (eds), Advances in Applied Phycology. Daya Publishing House, New Delhi, pp. 142-154.

De, P.K. 1939. The role of blue-green algae in nitrogen fixation in rice fields. Proc. R. Soc. Lond. 127B: 121139.

Desikachary, T.V. 1959. Cyanophyta. ICAR, New Delhi, India, pp. 1-686. 
Ernst, A., Black, T., Cai, Y., Panoff, J.M., Tiwari, D.N. and Wolk, C.P. 1992. Synthesis of nitrogenase in mutants of the cyanobacterium Anabaena sp. PCC 7120 affected in heterocyst development. J. Bacteriol. 174(19): 6025-6032.

Gupta, A.B. 1966. Algal flora and its importance in the economy of rice fields. Hydrobiologia 28(2): 213-222.

Gupta, A.B. and Shukla, A.C. 1969. Effects of algal extracts of Phormidium species on growth and development of rice seedlings. Hydrobiologia 34(2): 77-84.

Khan, Z.U.M., Begum, Z.N. Tahmida, Mandal, R. and Hossain, M.Z. 1994. Cyanobacteria in rice soils. World J. Microb. Biot. 10(3): 296-298.

Mishra, U., Choudhary, K.K., Pabbi, S., Dhar, D.W. and Singh, P.K. 2005. Influence of Blue Green Algae and Azolla inoculation on specific soil enzymes under paddy cultivation. Asian Jr. Microbiol. Biotechnol. Env. Sc. 7(1): 9-12.

Mitra, A.K. 1951. The algal flora of certain Indian soils. Indian J. Agric. Sci. 21: 357.

Roger, P.A. and Reynaud, P.A. 1979. Ecology of blue-green algae in paddy fields. In: International Rice Research Institute. Los Baňos, Philippines, pp. 289-309.

Singh, R.N. 1961. The role of blue-green algae in nitrogen economy of Indian Agriculture. ICAR Publication, New Delhi, pp. 175.

Singh, B.V., Choudhary, K.K., Dhar, D.W. and Singh, P.K. 2001. Occurrence of some Nostocales from 24 Parganas of West Bengal. Phykos 40 (1\&2): 83-87.

Singh, S.P. 1978. Succession of blue-green algae on certain sites near Varanasi. Indian J. Microbiol. 18(2): 128-130. 